\title{
KARAKTERISASI AGAR DARI HASIL PRODUKSI PETANI KABUPATEN BREBES SEBAGAI EKSIPIEN MUKOADESIF DALAM SEDIAAN FARMASI
}

\author{
Dhadhang Wahyu Kurniawan, Arif Budianto, dan Khilman Husna Pratama \\ Jurusan Farmasi Fakultas Ilmu-ilmu Kesehatan Universitas Jenderal Soedirman \\ email: dhadhang.wk@gmail.com
}

\begin{abstract}
Agar is widely used as a tablet binder, gel base, cream base, and the others in the manufacture of pharmaceutical dosage forms. Mucoadhesive drug delivery is expected to prolong the contact time of the drug in the mucus so that the maximum effect of the drug therapy. A number of studies have used that produced by the farmers in the district of Brebes as a tablet binder. However, for the quality of agar is not guaranteed, because the manufactured by home industry. The purpose of this study was to characterize agar in order to increase economic value and thus can reduce the dependence on imported raw materials for drugs Indonesia. The method used is to characterize the physical, chemical, and functional order. Data analysis used is to compare the test results to the existing literature. The results showed that the agar flour that has the characteristics: powder shape, white brownish and odorless; less irregular shape by SEM observation; many distributed on 100 mesh sieve (38.2\%); relatively less hygroscopic; relatively high moisture content; containing functional groups $\mathrm{C}$ $\mathrm{O}, \mathrm{C}=\mathrm{O}, \mathrm{CH}_{3}, \mathrm{CH}$, and $-\mathrm{OH}$ in its structure; classified as a weak base; viscosity increases with increasing concentration and decreasing temperature; have a relatively poor flow; has a rather good compressibility index; have different swelling behaviour in different media; and has a relatively weak mucoadhesive properties. The conclusion of this study is that agar flour from Gracilaria verrucosa less can be used as a mucoadhesive excipient in pharmaceutical dosage forms.
\end{abstract}

Keywords: excipients; agar; mucoadhesive; Brebes farmer; pharmaceutical dosage forms.

\begin{abstract}
ABSTRAK
Agar banyak digunakan sebagai bahan pengikat tablet, basis gel, basis krim, dan lain-lain dalam pembuatan sediaan farmasi. Penghantaran obat secara mukoadesif diharapkan dapat memperlama waktu kontak obat di mukus sehingga efek terapi obat tersebut maksimal. Sejumlah penelitian telah menggunakan agar yang dihasilkan oleh para petani di wilayah Kabupaten Brebes sebagai pengikat tablet. Namun demikian, agar yang digunakan belum diketahui mutunya secara pasti, karena diproduksi secara industri rumah tangga. Tujuan penelitian ini adalah melakukan karakterisasi agar supaya mutunya terukur sehingga nilai ekonomisnya meningkat dan dapat mengurangi ketergantungan terhadap impor bahan baku obat Indonesia. Metode yang digunakan adalah mengkarakterisasi secara fisika, kimia, dan fungsional agar. Analisis data yang digunakan adalah dengan membandingkan hasil pengujian terhadap literatur yang ada. Hasil penelitian menunjukkan bahwa tepung agar memiliki karakteristik: berbentuk serbuk, berwarna putih agak kecoklatan dan tidak berbau; di bawah pengamatan SEM bentuknya kurang beraturan; banyak terdistribusi pada ayakan 100 mesh $(38,2 \%)$; relatif kurang higroskopis; kandungan lembab relatif tinggi; mengandung
\end{abstract}


gugus fungsi $\mathrm{C}-\mathrm{O}, \mathrm{C}=\mathrm{O}, \mathrm{CH}_{3}, \mathrm{CH}$, dan $-\mathrm{OH}$ dalam strukturnya; tergolong dalam basa lemah; viskositasnya meningkat seiring meningkatnya konsentrasi dan turunnya suhu larutan; memiliki aliran yang relatif kurang baik; memiliki indeks kompresibilitas agak baik; memiliki daya mengembang yang berbeda pada media yang berbeda; dan memiliki sifat mukoadesif yang relatif lemah. Kesimpulan penelitian ini adalah tepung agar yang dihasilkan rumput laut jenis Gracilaria verrucosa kurang dapat digunakan sebagai eksipien mukoadesif dalam sediaan farmasi.

Kata kunci: eksipien; agar; mukoadesif; petani Brebes; sediaan farmasi.

\section{PENDAHULUAN}

Indonesia merupakan salah satu negara yang memiliki keanekaragaman hayati tinggi. Tetapi, sampai saat ini $96 \%$ bahan baku obat diimpor dari negara lain (Dwiprahasto, 2011). Menurut Kemenperin (2012), nilai impor bahan baku obat diprediksi mencapai Rp. 11,4 triliun pada tahun 2012 atau naik 8,5\% dibandingkan tahun sebelumnya yaitu $\mathrm{Rp}$. 9,59 triliun. Angka tersebut mencapai 95\% dari total nilai bisnis bahan baku obat di Indonesia. Indonesia termasuk satu dari empat negara di Asia (tiga lainnya Filipina, Myanmar, dan Vietnam) yang masih memiliki ketergantungan di bidang teknologi kesehatan. Padahal banyak bahan alam di Indonesia yang dapat digunakan menjadi bahan baku obat (Dwiprahasto, 2011).

Bahan baku impor yang banyak digunakan sebagai eksipien (bahan pembantu dalam sediaan farmasi) salah satunya adalah agar. Dalam pembuatan sediaan farmasi, agar banyak digunakan sebagai bahan pengikat tablet, basis gel, basis krim, dan lain-lain. Agar juga termasuk ke dalam biopolimer (Singh, 2011), suatu polimer yang menjadi pilihan pertama peneliti sebagai eksipien sediaan farmasi. Biopolimer disukai karena sifatnya yang memiliki toksisitas rendah, biodegradabel, stabil, dan termasuk dalam bahan dari alam yang terbarukan.

Salamat-Miller et al. (2005) memasukkan agar sebagai salah satu polimer mukoadesif yang digunakan dalam penghantaran obat secara bukal.
Penghantaran obat secara bukal yang menggunakan sistem mukoadesif diharapkan dapat memperlama waktu kontak obat di bukal sehingga efek terapi obat tersebut maksimal.

Sejauh ini, untuk mendapatkan agar kebanyakan diimpor, padahal negeri ini memiliki rumput laut yang banyak sekali. Ninda (2013) dalam penelitiannya telah menggunakan agar yang dihasilkan oleh para petani di wilayah Kabupaten Brebes sebagai pengikat tablet. Tablet yang dihasilkan cukup baik dan memenuhi seluruh persyaratan fisik yang sudah ditentukan. Namun demikian, agar yang digunakan belum diketahui mutunya secara pasti, karena dihasilkan dari industri rumah tangga.

Oleh karena itu, agar ini perlu dikarakterisasi lebih lanjut, terlebih karakterisasi sifat mukoadesifnya, supaya mutunya terukur sehingga nilai ekonomisnya meningkat dan dapat mengurangi ketergantungan terhadap impor bahan baku obat Indonesia. Karakterisasi yang dilakukan meliputi karakterisasi secara fisika, kimia, dan fungsional.

\section{METODE PENELITIAN}

\section{A. Bahan dan Alat Penelitian}

Bahan yang digunakan dalam penelitian ini antara lain: agar yang diproduksi oleh petani di wilayah Kabupaten Brebes, kalium dihidrogen fosfat $\left(\mathrm{KH}_{2} \mathrm{PO}_{4}\right)$, dinatrium hidrogen fosfat $\left(\mathrm{Na}_{2} \mathrm{HPO}_{4}\right)$, asam hidroklorida $(\mathrm{HCl})$, natrium hidroksida $(\mathrm{NaOH})$, akuades, 
$\mathrm{NaCl}$, lambung sapi segar, dan usus sapi segar. Pereaksi-pereaksi yang digunakan merupakan pereaksi dengan spesifikasi reagent grade.

Alat-alat yang digunakan dalam penelitian ini antara lain: timbangan analitik, pengaduk magnetik, texture analyzer, scanning electron microscope (SEM), waterbath, pengaduk, penyaring, spatula, viskometer Brookfield, alat pengukur waktu (stopwatch), jangka sorong, oven, pengayak bertingkat, flowmeter, sentrifugator, spektrofotometer uv, spektrofotometer inframerah, mucoadhesive tester (silinder berputar), alat uji waktu hancur, dissolution tester merk Erweka DT600, kertas saring, pot plastik, desikator, dan peralatan gelas.

\section{B. Metode}

\section{Karakterisasi fisik agar}

\section{Penampilan fisik}

Pengamatan

organoleptis dilakukan terhadap agar. Pengamatan yang dilakukan meliputi pengamatan terhadap bentuk, warna, dan bau (Ansel et al., 1999).

\section{Bentuk dan morfologi partikel}

Pemeriksaan dan pengamatan bentuk dan morfologi agar dilakukan dengan menggunakan scanning electron microscope (SEM). Sampel ditempelkan pada holder dengan menggunakan lem khusus, kemudian dimasukkan ke dalam coating unit untuk dilapisi dengan logam emas (Au). Pada tingkat kevakuman tertentu emas akan menguap dan melapisi partikel sampai pada holder. Holder berisi sampel dimasukkan ke dalam alat SEM, selanjutnya diamati dengan beberapa perbesaran.

\section{Distribusi ukuran partikel}

$\begin{array}{ccc}\text { Penentuan distribusi } & \text { ukuran } \\ \text { partikel dilakukan } & \text { dengan metode }\end{array}$ mikromeritik (ayakan). Pengayak yang sudah ditimbang disusun mulai dari atas, yaitu ayakan dengan mesh terkecil (40 mesh) hingga yang terbesar (120 mesh). Sejumlah 50 gram serbuk sampel agar dimasukkan pada pengayak dengan mesh terkecil kemudian alat dinyalakan selama 20 menit dengan kecepatan $15 \mathrm{rpm}$. Masing-masing pengayak berisi serbuk yang ditimbang. Setelah itu dicari persentase berat serbuk dan dibuat kurva distribusi ukuran partikelnya (Anonim, 1995).

$$
\% \text { berat serbuk }=\frac{b-a}{\text { berat sampel }} \times 100 \%
$$

Keterangan: $\quad \mathrm{a}=$ berat pengayak kosong $\mathrm{b}=$ berat pengayak yang berisi serbuk

\section{Higroskopisitas}

Serbuk sampel agar ditimbang sebanyak \pm satu gram. Sampel tersebut ditempatkan pada pot plastik dengan empat perlakuan yaitu:

1. pot plastik tanpa tutup,

2. pot plastik dengan tutup,

3. pot plastik tanpa tutup dengan silika gel, dan

4. pot plastik dengan tutup dengan silika gel.

Masing-masing pot plastik ditempatkan dalam desikator pada suhu kamar dengan kelembaban (RH) 70\% yang telah diatur dengan larutan jenuh $\mathrm{NaCl}$. Sampel diamati setiap minggu terhadap perubahan karakteristik fisiknya meliputi perubahan warna dan bobotnya selama 1 bulan (Cartensen, JT dan Rhodes, CT., 2000).

\section{Pemeriksaan kandungan lembab}

Sebanyak 5 gram tepung agar dikeringkan di dalam oven pada suhu $40^{\circ} \mathrm{C}$ , kemudian ditimbang sampai diperoleh bobot yang konstan. Kandungan lembab dihitung menggunakan persamaan:

$$
\frac{w o-w 1}{w o} \times 100 \%
$$

Keterangan: $\mathrm{w} 0=$ berat serbuk awal $(\mathrm{g})$ 
$\mathrm{W} 1=$ berat serbuk setelah pemanasan.

Syarat kandungan lembab yang baik adalah pada rentang $2-4 \%$ (Lachman et al., 1994).

\section{Karakterisasi kimia agar}

\section{Identifikasi gugus fungsi}

Serbuk sampel dicampurkan dengan kristal $\mathrm{KBr}$, kemudian digerus hingga homogen. Campuran ini dimasukkan ke dalam suatu wadah yang berbentuk cakram untuk membentuk pelet. Pelet ini kemudian langsung dianalisis menggunakan spektrofotometer inframerah (Fourier Transformation Infra Red/FTIR). Hasilnya akan diperoleh spektrum inframerah yang berguna untuk mengetahui gugus fungsi yang terdapat dalam agar.

\section{Pengukuran pH}

Pengukuran $\mathrm{pH}$ dilakukan dengan membuat larutan agar $2 \% \mathrm{~b} / \mathrm{v}$ dalam akuades, kemudian diukur dengan menggunakan $\mathrm{pH}$ meter.

\section{Karakterisasi fungsional}

\section{Pengukuran viskositas agar}

Pengukuran viskositas dilakukan dengan membuat larutan agar $5 \% \mathrm{~b} / \mathrm{v}$ dalam akuades, kemudian diukur dengan menggunakan viskosimeter Brookfield.

\section{Pemeriksaan sifat alir serbuk}

Pemeriksaan sifat alir serbuk dilakukan dengan metode sudut diam dan waktu alir.

\section{Metode sudut diam}

Metode pengukuran sudut diam dilakukan dengan menimbang $100 \mathrm{~g}$ granul, kemudian granul dimasukkan ke dalam corong uji waktu alir yang berdiri bebas pada ketinggian $\mathrm{H}$ di atas kertas grafik pada bidang horizontal. Penutup corong dibuka sehingga granul keluar dan ditampung pada bidang datar (Cartensen dan Rhodes, 2000). Sudut diam granul dapat dihitung dengan rumus:

$$
\operatorname{Tan} \alpha=\frac{\mathrm{H}}{\mathrm{R}} \text { atau } \alpha=\arctan \frac{\mathrm{H}}{\mathrm{R}}
$$

Keterangan: $\quad \alpha=$ sudut istirahat/sudut

$$
\text { diam }
$$

$$
\begin{aligned}
& \mathrm{H}=\text { tinggi tumpukan } \mathrm{C} \\
& \mathrm{R}=\text { jari-jari tumpukan granul } \\
& \quad \text { atau } 1 / 2 \mathrm{~d}
\end{aligned}
$$

\section{Waktu alir}

Metode pengukuran waktu alir dilakukan dengan menimbang $100 \mathrm{~g}$ granul, kemudian granul dimasukkan kedalam corong yang ujung tangkainya ditutup. Penutup corong dibuka dan granul dibiarkan mengalir sampai habis. Dihitung waktu alir granul. Granul mempunyai sifat alir bagus bila mempunyai waktu alir tidak lebih dari 10 detik.

\section{Indeks kompresibilitas}

Berat jenis bulk diukur dengan menimbang sejumlah massa (m) sampel agar sebanyak 20 gram dimasukkan ke dalam gelas ukur $100 \mathrm{~mL}$, selanjutnya diukur volumenya (V1).

$$
\text { berat jenis bulk }=\frac{m}{V 1}
$$

Berat jenis mampat diukur dengan melanjutkan pengukuran berat jenis bulk, kemudian gelas ukur yang berisi sampel tadi diketuk-ketukkan sebanyak 300 kali. Percobaan diulangi dengan 300 ketukan kedua untuk memastikan sampelnya tidak mengalami penurunan volume, selanjutnya diukur volumenya (V2) (Lachman et al., 1994).

berat jenis mampat $=\frac{m}{V 2}$
Indeks kompresibilitas $=\frac{\text { BJ mampat }- \text { BJ bulk }}{\text { BJ mampat }} \times 100 \%$

Indeks kompresibilitas dan kategorinya dapat dilihal pada Tabel 1. 
Tabel 1. Indeks Kompresibilitas, sudut diam, rasio Hausner dan kategorinya

\begin{tabular}{|c|c|c|l|}
\hline $\begin{array}{c}\text { Sudut } \\
\text { diam }\left({ }^{\circ}\right)\end{array}$ & $\begin{array}{c}\text { Indeks } \\
\text { kompresibilitas }(\%)\end{array}$ & $\begin{array}{c}\text { Rasio } \\
\text { Hausner }\end{array}$ & \multicolumn{1}{|c|}{ Kategori } \\
\hline $25-30$ & $<10$ & $1,00-1,11$ & Istimewa \\
\hline $31-35$ & $11-15$ & $1,12-1,18$ & Baik \\
\hline $36-40$ & $16-20$ & $1,19-1,25$ & Cukup baik \\
\hline $41-45$ & $21-25$ & $1,26-1,34$ & Agak baik \\
\hline $46-55$ & $26-31$ & $1,35-1,45$ & Buruk \\
\hline $56-65$ & $32-37$ & $1,46-1,59$ & Sangat buruk \\
\hline$>66$ & $>38$ & $>1,60$ & Sangat buruk sekali \\
\hline
\end{tabular}

[Sumber: The United States Pharmacopoeia Convention, 2007]

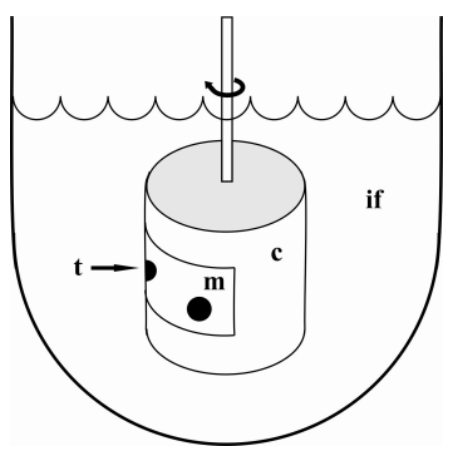

Gambar 1. Skema sistem pengujian yang digunakan untuk mengevaluasi sifat mukoadesif tablet berdasarkan macam-macam polimer. c: cylinder, if: intestinal fluid, $\mathrm{m}$ : mukosa usus sapi, t: tablet (Bernkop-Schnurch, 2002).

\section{Uji daya mengembang}

Sampel dimasukkan ke dalam gelas ukur $10 \mathrm{~mL}$ sampai dengan batas 1 mL. Pada sampel tersebut ditambahkan larutan $\mathrm{HCl} \mathrm{pH}$ 1,2 atau dapar fosfat $\mathrm{pH}$ 7,4 masing-masing sebanyak $10 \mathrm{~mL}$ pada wadah yang berbeda. Agar dibiarkan mengembang pada suhu ruang. Volume agar dihitung berdasarkan batas permukasan antara agar dengan larutan uji.

Persentase daya mengembang dari agar dihitung berdasarkan rumus berikut:

$\%$ Daya Mengembang $=\frac{V t-V 0}{V 0} \times 100 \%$
Keterangan:

$\mathrm{V} 0=$ volume awal agar sebelum uji daya mengembang $(\mathrm{mL})$

$\mathrm{Vt}=$ volume akhir agar setelah uji daya mengembang pada waktu tertentu $(\mathrm{mL})$.

\section{Evaluasi in vitro sifat mukoadesif} dengan metode silinder berputar

Tablet agar dilekatkan pada mukosa usus sapi yang baru dipotong, yang telah ditempelkan pada silinder stainless steel (diameter 4,4 cm, tinggi 5,1 $\mathrm{cm}$, perangkat 4-silinder, USP XXVI) menggunakan perekat cyanoacrylate. Silinder ditempatkan di alat disolusi menurut USP, tenggelam seluruhnya di 
dalam medium disolusi dapar fosfat $\mathrm{pH}$ 6,8 , pada temperatur $37^{\circ} \mathrm{C}$ dan diaduk pada $50 \mathrm{rpm}$. Alat pengujian dapat dilihat pada Gambar 1. Tablet uji yang terlepas, terdisintegrasi dan/atau tererosi diamati selama jangka waktu 10 jam (BernkopSchnurch, 2002).

\section{Analisis Data}

Data hasil karakterisasi agar dibandingkan dengan persyaratan menurut literatur.

\section{HASIL DAN PEMBAHASAN}

Hasil determinasi tanaman menunjukkan bahwa rumput laut yang dihasilkan oleh petani di kawasan Pantai Randusanga Kabupaten Brebes adalah jenis Gracilaria verrucosa.

\section{Karakterisasi fisik tepung agar}

Agar kertas tidak memiliki bau yang khas. Setelah dihaluskan menggunakan blender, agar-agar kertas ini seperti tepung pada umumnya, dan dikenal dengan istilah tepung agar. Tepung agar ini kemudian dikarakterisasi fisik terhadap bentuk dan morfologinya yang dilakukan dengan menggunakan scanning electron microscope (SEM). Pada Gambar 2 terlihat bahwa bentuk dan morfologi tepung agar kurang beraturan.

Bentuk yang kurang beraturan ini disebabkan oleh proses penghalusan yang menggunakan blender. Apabila ingin mendapatkan bentuk tepung agar yang relatif seragam akan lebih baik menggunakan mesin penghalus yang dapat divalidasi.

Hasil penentuan distribusi ukuran partikel yang dilakukan dengan metode mikromeritik (ayakan) dapat dilihat pada Gambar 3.

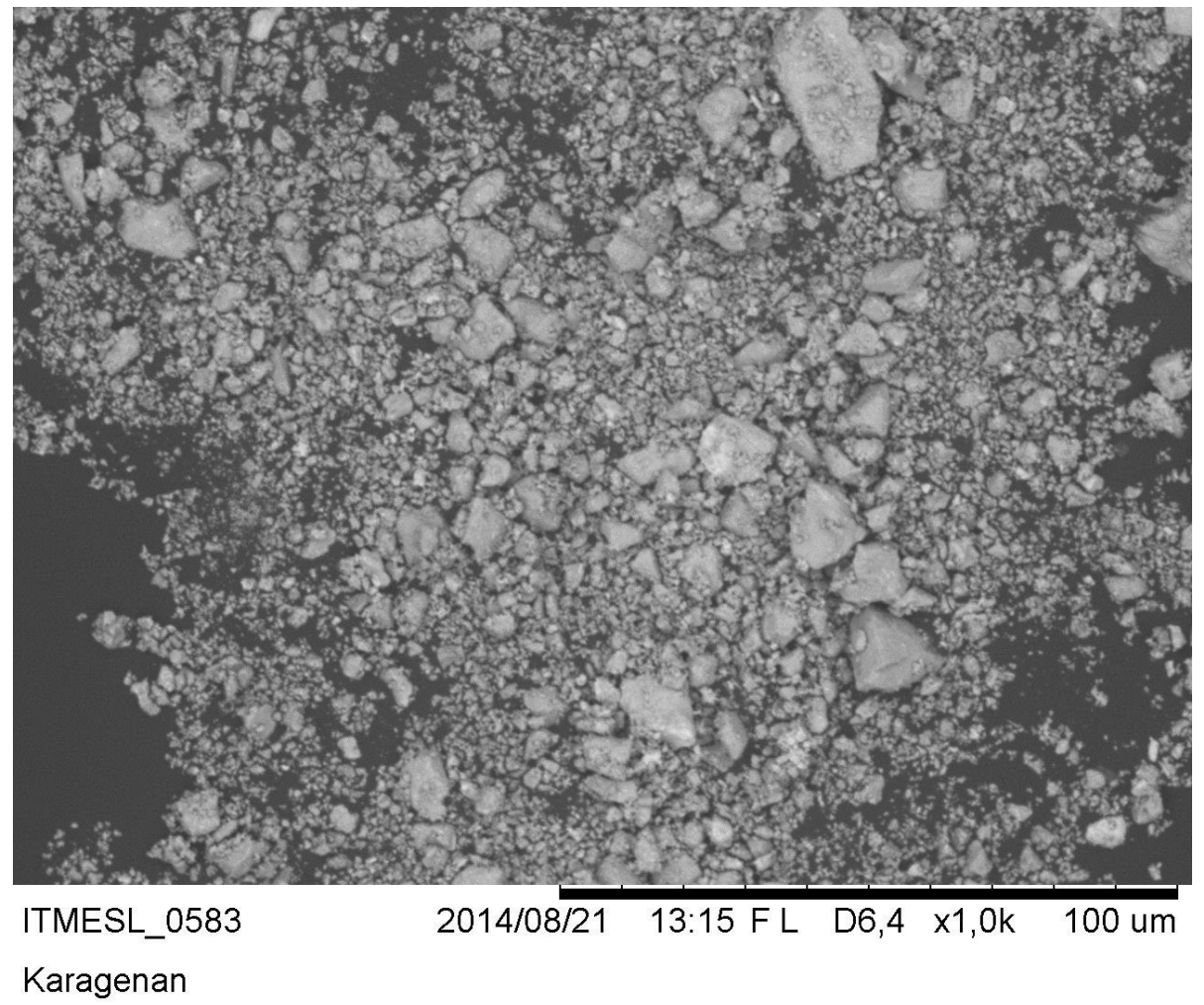

Gambar 2. Bentuk dan morfologi tepung agar di bawah pengamatan SEM. 


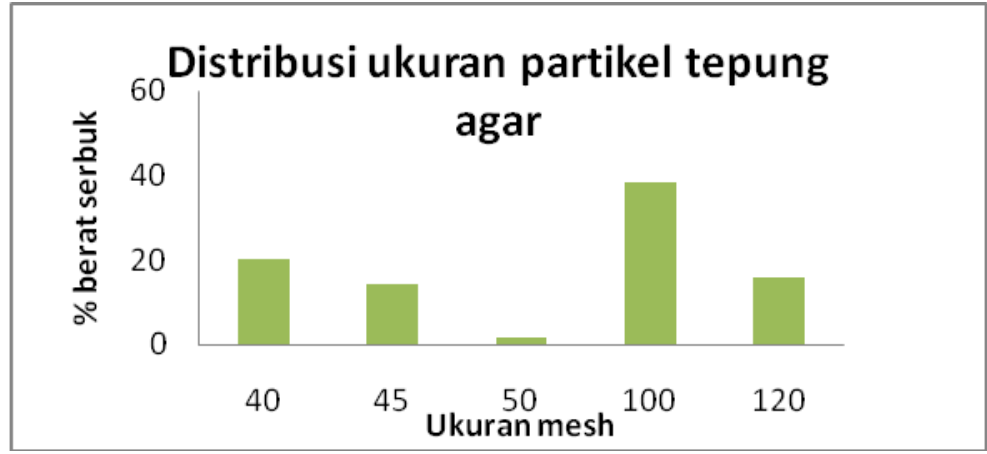

Gambar 3. Distribusi ukuran partikel tepung agar.

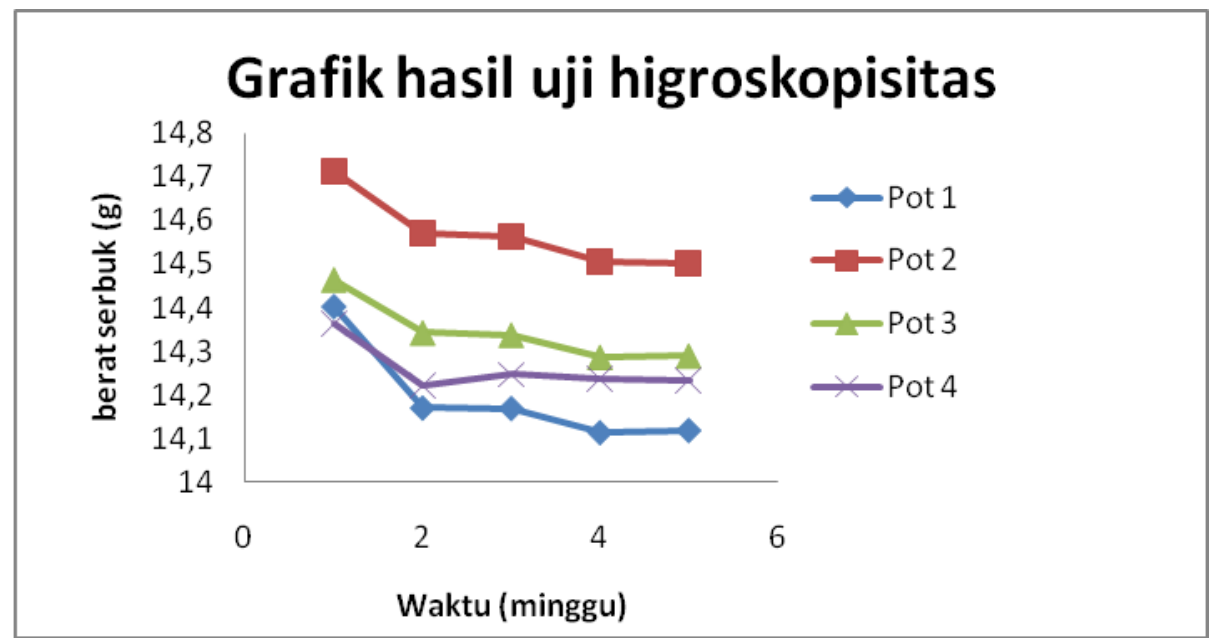

Gambar 4. Grafik hasil uji higroskopisitas.

Berdasarkan Gambar 3 terlihat bahwa tepung agar pada ayakan 100 mesh memiliki bagian paling banyak, yaitu $38,2 \%$, diikuti 40 mesh (20\%), 120 mesh $(15,6 \%), 45$ mesh $(14,4 \%)$, dan 50 mesh $(1,6 \%)$. Hal ini dapat dinyatakan bahwa sebagian besar tepung agar berbentuk serbuk.

Karakterisasi sifat higroskopisitas tepung agar dilakukan di dalam desikator pada suhu $28,5^{\circ} \mathrm{C}$ dan kelembaban relatif (RH) 70\%. Hasil uji higroskopisitas tersebut dapat dilihat pada Gambar 4.

$$
\text { Berdasarkan hasil uji }
$$

higroskopisitas terlihat bahwa dari waktu ke waktu terjadi penurunan berat serbuk pada masing-masing pot plastik. Penurunan berat yang relatif tajam ditemukan pada pot 1 pada minggu pertama. Hal ini menunjukkan bahwa pot yang tanpa tutup relatif mengalami banyak penguapan/penyusutan tepung agar. Terjadinya penyusutan tepung agar ini dapat dianggap bahwa tepung agar dalam penelitian ini relatif rendah atau relatif tidak higroskopis.

Selama pengamatan uji higroskopisitas tidak ditemukan terjadinya perubahan warna pada setiap pot plastik. Hal ini dapat dinyatakan bahwa tepung agar relatif stabil terhadap adanya oksidasi dan/atau fotooksidasi.

Pemeriksaaan kandungan lembab dilakukan secara manual, hasil yang diperoleh menunjukkan bahwa kandungan lembab tepung agar dalam penelitian ini adalah 19,76\%. Hal ini sangat jauh dari persyaratan, kemungkinan karena ketika pembuatan agar kertas para petani tidak memantau kondisi kelembaban. Oleh 
karena itu, supaya diperoleh data kandungan lembab tepung agar yang baik perlu dilakukan standarisasi proses pembuatan tepung agar.

\author{
Karakterisasi kimia tepung agar \\ Setelah dilakukan analisis \\ menggunakan spektrofotometer \\ inframerah, diperoleh hasil seperti yang \\ terlihat pada Gambar 5.
}

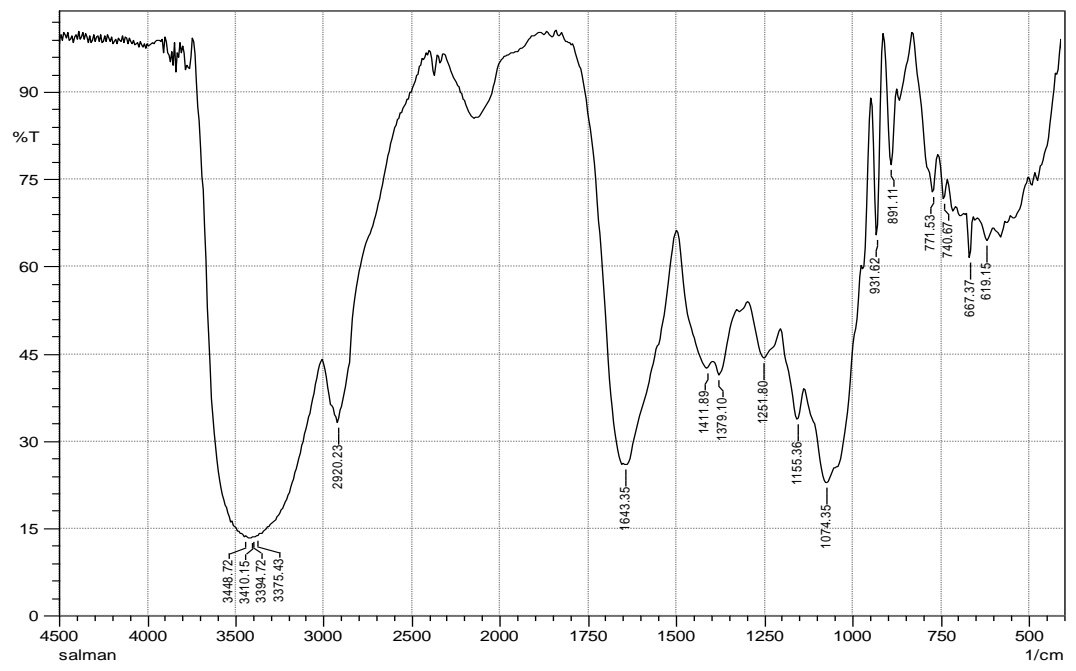

Gambar 5. Spektrum inframerah tepung agar.

Berdasarkan gambar spektrum tersebut dapat dinyatakan bahwa gugus fungsi yang dimiliki oleh tepung agar dalam penelitian ini antara lain: $\mathrm{C}-\mathrm{O}$, $\mathrm{C}=\mathrm{O}, \mathrm{CH}_{3}, \mathrm{CH}$, dan $-\mathrm{OH}$.

Pengukuran $\mathrm{pH}$ dilakukan dengan membuat larutan tepung agar $2 \% \mathrm{~b} / \mathrm{v}$ dalam akuades, kemudian diukur dengan menggunakan $\mathrm{pH}$ meter. Dengan mengetahui $\mathrm{pH}$ agar, kita dapat mengetahui sifat keasaman dari tepung agar. Hasil pengukuran $\mathrm{pH}$ dapat dilihat pada Tabel 2.

Tabel 2. Data hasil pengujian $\mathrm{pH}$ tepung

\begin{tabular}{|c|c|c|}
\hline agar \\
\hline No. & Pada suhu $\left({ }^{\circ} \mathrm{C}\right)$ & $\mathrm{pH}$ \\
\hline 1. & 94 & 8,4 \\
\hline 2. & 60 & 8,6 \\
\hline 3. & 36 & 7,4 \\
\hline
\end{tabular}

Pengujian $\mathrm{pH}$ dilakukan pada suhu yang berbeda-beda, karena larutan tepung agar pada suhu yang semakin rendah memiliki kecenderungan berbentuk gel. Menurut Rasyid (2004), agar memiliki sifat tidak larut dalam air dingin, tetapi terlarut dalam air mendidih. Suhu pembekuan agar adalah antara $35-39{ }^{\circ} \mathrm{C}$ dan titik leburnya adalah antara $85-95$ ${ }^{\circ} \mathrm{C}$.

\section{Karakterisasi fungsional tepung agar}

Pengukuran viskositas dilakukan dengan membuat larutan agar $5 \% \mathrm{~b} / \mathrm{v}$ dalam akuades, kemudian diukur dengan menggunakan viskosimeter Brookfield. Hasil pengukuran viskositas dapat dilihat pada Tabel 3. 
Tabel 3. Hasil pengukuran viskositas tepung agar

\begin{tabular}{|c|c|c|}
\hline No. & Pada suhu $\left({ }^{\circ} \mathrm{C}\right)$ & Viskositas $(\mathrm{cP})$ \\
\hline 1. & 90 & 6.600 \\
\hline 2. & 70 & 8.800 \\
\hline 3. & 68 & 12.000 \\
\hline 4. & 40 & Cenderung berbentuk gel \\
\hline
\end{tabular}

Berdasarkan hasil pengukuran viskositas tersebut, terlihat bahwa semakin rendah suhu pengukuran, viskositas larutan tepung agar semakin tinggi. Salah satu sifat agar yang sangat unik adalah kemampuannya dapat membentuk gel, meskipun dalam konsentrasi larutan yang sangat encer, misalnya $0,04 \%$. Namun apabila agar dengan konsentrasi yang lebih besar dari $0,5 \%$, maka akan membentuk gel yang kaku dan terbebas dari keberadaan garam (Rasyid, 2004).

Pemeriksaan sifat alir tepung agar dilakukan dengan metode sudut diam dan waktu alir. Masing-masing pemeriksaan dilakukan replikasi tiga kali, diperoleh hasil bahwa sudut diamnya $38,13^{\circ}$ dan waktu alirnya adalah 16,67 g/detik. Dengan demikian dapat dinyatakan bahwa sifat alir tepung agar relatif kurang baik. Suatu bahan dinyatakan memiliki sifat alir yang baik apabila memiliki sudut diam kurang dari $30^{\circ}$ dan memiliki waktu alir kurang dari $10 \mathrm{~g} /$ detik.

Hasil pengukuran indeks kompresibilitas menginformasikan bahwa, tepung agar memiliki indeks kompresibilitas sebesar 20,91\%. Berdasarkan USP Convention (2007), angka ini tergolong agak baik. Indeks kompresibilitas merupakan salah satu parameter kemampuan suatu bahan untuk dapat dikompresi menjadi suatu tablet. Dengan demikian, tepung agar dapat dianggap memiliki potensi yang baik apabila digunakan sebagai eksipien dalam formulasi suatu tablet.

Sifat lain yang perlu diperhatikan dalam pengembangan bahan baku untuk eksipien sediaan farmasi adalah daya mengembang bahan tersebut. Setelah dilakukan pengujian daya mengembang tepung agar, diperoleh kurva seperti pada Gambar 6.

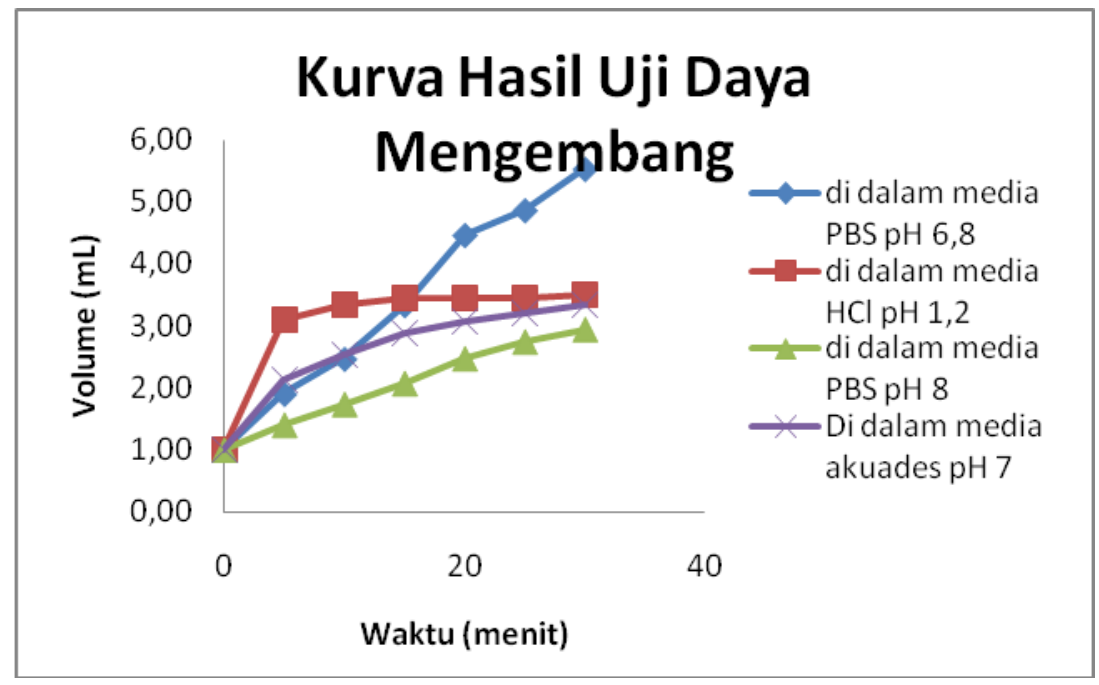

Gambar 6. Kurva hasil uji daya mengembang tepung agar. 
Berdasarkan gambar terlihat, tepung agar pada media PBS pH 6,8 masih cenderung mengalami pengembangan setelah menit ke-30, demikian juga dalam media PBS pH 8 dan media akuades pH 7. Sementara di dalam media $\mathrm{HCl} \mathrm{pH} 1,2$, tepung agar relatif kurang mengembang setelah menit ke-30. Data sifat daya mengembang ini penting sekali terkait dengan penggunaan tepung agar sebagai eksipien dalam sediaan farmasi. Dengan mengetahui kemampuan mengembang tepung agar, dapat menjadi data sekiranya tepung agar memiliki kemampuan mengembang yang optimal pada $\mathrm{pH}$ berapa terkait dengan tujuan penghantaran obat yang efektif pada target obatnya.

Karakter utama suatu bahan apabila akan digunakan sebagai eksipien untuk sediaan farmasi yang bekerja secara mukoadesi adalah kemampuan mukoadesif bahan tersebut. Evaluasi in vitro sifat mukoadesif dengan metode silinder berputar terhadap tepung agar diperoleh hasil bahwa tablet tepung agar melekat di usus sapi segar selama 23,41 detik. Hasil ini relatif kurang kuat jika dibandingkan dengan kitosan dan natrium alginat (Kurniawan et al., 2014). Perlekatan tablet pada mukosa usus dapat dilihat pada Gambar 7.

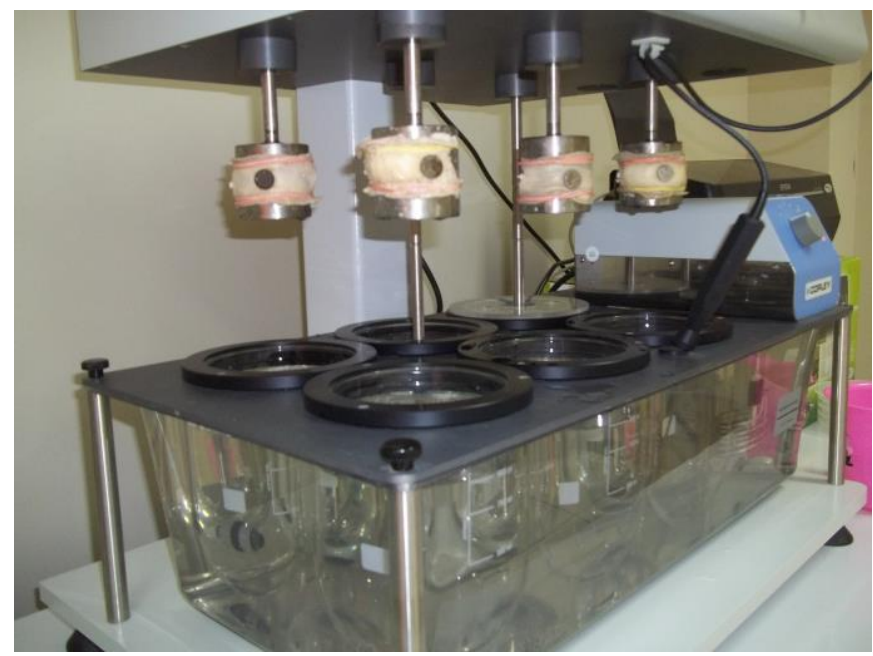

Gambar 7. Perlekatan tablet pada mukosa usus

\section{KESIMPULAN}

Tepung agar yang dihasilkan oleh para petani di wilayah Kabupaten Brebes memiliki karakteristik antara lain: secara organoleptis berbentuk serbuk, berwarna putih agak kecoklatan dan tidak berbau; di bawah pengamatan SEM bentuknya kurang beraturan; banyak terdistribusi pada ayakan 100 mesh $(38,2 \%)$; relatif kurang higroskopis; kandungan lembab relatif tinggi; mengandung gugus fungsi $\mathrm{C}$ $\mathrm{O}, \mathrm{C}=\mathrm{O}, \mathrm{CH}_{3}, \mathrm{CH}$, dan $-\mathrm{OH}$ dalam strukturnya; tergolong dalam basa lemah; viskositasnya meningkat seiring meningkatnya konsentrasi dan turunnya suhu larutan; memiliki aliran yang relatif kurang baik; memiliki indeks kompresibilitas agak baik; memiliki daya mengembang yang berbeda pada media yang berbeda; dan memiliki sifat mukoadesif yang relatif lemah. Tepung agar yang dihasilkan rumput laut jenis Gracilaria verrucosa ini kurang dapat digunakan sebagai eksipien mukoadesif dalam sediaan farmasi.

\section{UCAPAN TERIMA KASIH}

Terima kasih disampaikan kepada Lembaga Penelitian dan Pengabdian 
Masyarakat (LPPM) Unsoed yang telah mendanai jalannya penelitian ini.

\section{DAFTAR PUSTAKA}

1. Agoes, G., 2008, Sistem Penghantaran Obat Pelepasan Terkendali, Penerbit ITB, Bandung, 33-34, 231-244.

2. Anonim, 1995, Farmakope Indonesia edisi IV, 4-7, 489, 515, 519, 551, 713, 771, 999, Departemen Kesehatan Republik Indonesia, Jakarta.

3. Ansel, H.C., Allen Jr. L.V., dan Popovich, N.G, 1999, Pharmaceutical Dosage Forms and Drug Delivery Systems. Philadelphia: Lippincott Williams and Wilkins. 60-62.

4. Bernkop-Schnurch, A., 2002, Mucoadhesive Polymers in Polymeric Biomaterials, Severian Dumitriu (Editor), Marcell Dekker Inc., New York, p. 147-162.

5. Distantina, S., Wiratni, Fahrurrozi, M., dan Rochmadi, 2011, Carrageena Properties Extracted from Eucheuma cottonii, Indonesia, World Academy of Science, Engineering and Technology 78, 738-742.

6. Dwiprahasto, I., 2011, 96 Persen Bahan Obat di Indonesia Impor, http://www.tempo.co/read/news/2011/ 11/30/173369286/96-Persen-BahanObat-di-Indonesia-Impor, diakses 30 April 2012.

7. Cartensen, J.T. dan Rhodes, C.T, 2000, Drug Stabilty Principles and Practices 3rd Edition, Marcell Dekker Inc. New York, 215-229.

8. Gurny, R., Meyer, J-M., dan Peppas, N.A., 1984, Bioadhesive intraoral release systems: Design, testing and analysis, Biomaterials, Vol 5 November, 337.

9. Kemenperin, 2012, Impor Bahan Obat Tembus Rp. 11 Triliun, http://www.kemenperin.go.id/artikel/2 808/Impor-Bahan-Obat-Tembus-Rp11-T, diakses 30 April 2012.

10. Kurniawan, D.W., Maulana, B., Pratiwi, H., dan Ikaditya, L., 2014, Komparasi Kitosan dan Natrium
Alginat sebagai Polimer Mukoadesif dalam Tablet Ekstrak Etanol Herba Sambiloto (Andrographis paniculata), Prosiding Seminar Nasional Perkembangan Terkini Sains Farmasi dan Klinik 4, Fakultas Farmasi Universitas Andalas, Padang.

11. Lachman L., Herbert A.L., dan Joseph L.K., 1994, Teori dan Praktek Farmasi Industri. Alih Bahasa Siti Suyatmi. Edisi 3, Jilid 2. UI Press, Jakarta: 643730.

12. Martin, A., Bustamante, P., dan Chun, A.. 1993, Physical pharmacy: Physical chemical principles in the pharmaceutical science. (4th ed.). Philadelphia: Lea \& Febiger, 497-452.

13. Necas, J. dan Bartosikova, L., 2013, Carrageenan: a review, Veterinarni Medicina, 58 (4); 187-205.

14. Ninda, Ratih Juwita, 2013, Formulasi Tablet dari Ekstrak Etanol Bawang Merah (Allium cepa) sebagai Antidiabetes Menggunakan Pengikat Agar, Skripsi, Jurusan Farmasi FKIK Unsoed, Purwokerto.

15. Nugroho B.A dan Puwaningsih E, 2006, Perbedaan Diet Ekstrak Rumput Laut (Eucheuma sp.) dan Insulin dalam Menurunkan Kadar Glukosa Darah Tikus Putih (Rattus norvegicus) Hiperglikemik, Media Medika Indonesia, Vol. 41 No. 1, 23-30.

16. Rasyid, Abdullah, 2004, Beberapa Catatan tentang Agar, Oseana, Volume XXIX, Nomor 2, $1-7$.

17. Rowe, R.C., Sheskey, P.J., dan Quinn, M.E., 2009, Handbook of Pharmaceutical Excipients $6^{\text {th }}$ edition, Pharmaceutical Press and American Pharmacists Association, p. 159-161, 283-286.

18. Salamat-Miller N., Chittchangi, M., dan Johnston, T.P., 2005, The use mucoadhesive polymers in buccal drug delivery, Advanced Drug Delivery Reviews, 57, 1666-1691.

19. Singh, A., 2011, Biopolymers in Drug Delivery: A Review, Pharmacologyonline, 1, 666-674. 
20. Smart, D. Jhon, 2005, The basic and underlying mechanisms of mucoadhesion, Advance Drug Delivery Reviews 57. 1556-1568.

21. Sreenivas, S.A. dan Pai, K.V., 2008, Thiolated Chitosans: Novel Polymers for Mucoadhesive Drug Delivery - A Review, Tropical Journal of Pharmaceutical Research, September 2008; 7 (3): 1077-1088.

22. The United States Pharmacopoeia Convention, 2007, United States Pharmacopoeia 30th and National Formulary 25th (CD-ROM).

23. Velde, F.V., dan Ruiter, G.A, 2005, Carrageenan, Dalam: Polysaccharides and Polyamides in The Food Industry:
Properties, Production, and Patents, Weinhelm: Wiley-VCH GmbH \& Co. 88, 102-105.

24. Wade, A dan P.J. Weller, 2006, Handbook of Pharmaceutical Excipients, 5th Edition, London: The pharmaceutical Press, 485,491.

25. WHO, 1999, Safety Evaluation of Certain Food Additives, WHO Food Additives Series, Genewa, 42.

26. Yasita, Dian, dan Intan Dewi R., 2008, Optimasi Proses Ekstraksi Pada Pembuatan Agar Dari Rumput Laut Eucheuma Cottoni Untuk Mencapai Foodgrade, Jurusan Teknik Kimia, Fakultas Teknik Universitas Diponegoro, Semarang. 